УДК: $351: 338.432$

DOI https://doi.org/10.32838/TNU-2663-6468/2021.2/017

\title{
Гурський М.М.
}

аспірант кафедри публічного управління

та менеджменту організацій

Чернігівського національного

технологічного університету

\section{МЕХАНІЗМ РЕГУЛЮВАННЯ ЗЕЛЕНОГО КУРСУ В АГРАРНОМУ СЕКТОРІ УКРАЇНИ}

У статті на прикладі застосування органічного виробнищтва та зеленого курсу в аграрному секторі економіки Украӥни, розкрито питання механізму регулювання зеленого курсу в аграрному секторі економіки; запропоновано рекомендаиії органам державної влади та місцевого самоврядування щодо підвищення ефективності використання бюджетних коштів виділених на розвиток аграрної галузі та сільського господарства держави. Побудова зеленої економіки в Україні зараз є стрижнем Угоди про асоиіаиію між Украйною та Свропейським Союзом, яка включає перелік відповідних директив і нормативних актів, що полегшують перехід до зеленої економіки. Реалізачія ичих правових актів носить добровільний характер, але може розглядатися як передумова для повної економічної інтеграчії Украӥни з СС. Ідентифіковані політичні, економічні та технічні причини, чому процес зеленої трансформаиії в Україні йде такими повільними темпами. У політичному плані зелений вимір поки щзо не інтегрований або не повністю інтегрований в порядок денний українського парламенту та національного уряду, проте ие можна змінити. Економічні причини пов'язані з фінансовою системою, яка занадто сильно покладається на вуглецемісні галузі та викопне паливо. Для досягнення поставлених иілей запропоновано такі шляхи: 1) підтримка органічного виробництва: виконання програм з підтримки виробників органічної продукиії; здійснення заходів, спрямованих на підвищення рівня обізнаності виробників стосовно переваг ведення органічного виробництва; 2) збільшення виробництва органічної продукиії: розроблення програм фінансової та дорадчої підтримки виробників органічної продукиї; залучення більшої кількості виробників до ведення органічного виробництва шляхом удосконалення державного регулювання в зазначеній сфері; 3) забезпечення розвитку сталого виробництва: заохочення сталого сільськогосподарського виробництва, захисту навколишнього природного середовища і тварин, поширення застосування методів органічного виробнищтва і використання біотехнологій, «кліматично розумного» сільського та лісового господарства із скороченням викидів парникових газів та адаптачією до зміни клімату, сталого управління природними ресурсами та збереження і примноження біорізноманіття.

Ключові слова: державне управління, державне регулювання, агропромисловий комплекс, державна підтримка агропромислового комплексу, сільськогосподарські підприємства, особисті селянські господарства, зелений курс.

Постановка проблеми. Вирішуючи актуальне питання євроінтеграції України до зеленого курсу $€ \mathrm{C}$, необхідно враховувати сильні і слабкі сторони національної економіки та об'єктивно оцінювати потенційні ризики у сфері поширення зеленого курсу на вітчизняний аграрний сектор. Стратегією $\mathrm{CC}$ «від лану до столу» у контексті зеленого курсу передбачає до 2030 року мінімізації використання небезпечних пестицидів й антибіотиків у галузі тваринництва на 50\%, добрив - на 20\%, значного розширення частки органічного виробництва до $25 \%$ від загального. Як відомо, Європейський зелений курс (European Green Deal) - дорожня карта заходів щодо перетворення Свропи на перший у світі кліматично нейтральний континент до 2050 року. Водночас курс має стимулювати розвиток економіки, покращити здоров'я та якість життя людей. Відтак, значної уваги нині потребують питання щодо зеленого курсу в агропромисловому комплексі країни та механізми покращення регулювання використання бюджетних коштів, що виділялися на виконання бюджетних програм щодо реалізації державної політики в аграрному секторі економіки держави а також розробки конкретних пропозицій щодо підвищення ефективності їх використання. 
Аналіз останніх досліджень і публікацій. В основі дослідження $є$ аналіз законодавчої, нормативно-методологічної бази 3 питань реалізації державного регулювання в аграрному секторі економіки, який здійснювали М. Баланівський, В. Тарасенко, В. Єрмоленко, І. Лопушинський, T. Шестаковська та інші. На сьогодні не розкритими залишаються питання щодо інструментів реалізації механізмів державного регулювання зеленого курсу аграрного сектору України.

Метою статті. Розробити рекомендації органам державної влади та органам місцевого самоврядування щодо конкретних механізмів державної підтримки аграрного сектору які проводять органічне виробництво та взяли напрямок на зелений курс.

Виклад основного матеріалу. Зелений курс аграрного сектору був офіційно представлений Президентом ЄК Урсулою фон дер Ляєн в Європарламенті 11 грудня 2019 року. Ключові його напрями: чиста енергія, кліматична дія, будівництво та реновація, стійка промисловість, стійка мобільність, зменшення забруднення довкілля, біорозмаїття, стійка аграрна політика (стратегія «Від лану до столу»). В Україні внутрішні дискусії з бізнес-колами щодо Європейського зеленого курсу почалися у 2020 році.

Про зелені стратегії зараз говорять всі політичні та громадські лідери на всіх континентах. Збагнути необхідність зелених змін - це вже половина на шляху до результату. Будь-яка стратегія - складна, багатопланова діяльність, що передбачає не тільки усвідомлення проблеми, основних напрямків та ключових показників, а й певну послідовність спрямованих сукупних дій усіх активістів такого процесу. Реалізація стратегії стає можливою тільки за умови здатності ії̈ учасників передбачити можливі наслідки своїх дій, готовності до планування спільних послідовних кроків, уміння визнавати помилки та вчасно корегувати їх, знаходити нестандартні способи розв'язання проблеми. Саме про конкретні кроки зараз і варто говорити, адже стратегія не містить удачі або випадкових елементів, розуміти ії замало - треба діяти.

Кабінет Міністрів України 3 березня затвердив Постанову «Про затвердження Національної економічної стратегії на період до 2030 року», де офіційно встановлено ціль щодо \% земель під органічним виробництвом - згідно з індикаторами стратегії планується досягти показника площі земель 3 органічним статусом не менш як $3 \%$ загальної площі сільськогосподарських угідь України, що становить приблизно 1,3 млн га [1].
Згідно даних оперативного моніторингу, що були зібрані Міністерством розвитку економіки, торгівлі та сільського господарства України, станом на 31.12.2019 під органічним виробництвом в Україні було зайнято близько 468 тис га. Тобто фактично за 10 років планується збільшення площі під органічним в три рази. Ще один індикатор стратегії - збільшення експорту органічної продукції до 1 млрд доларів США до 2030 року.

Пандемія, що тривала протягом року, i, як наслідок, локдауни, серйозно вплинули на життя та добробут людей у всьому світі. Соціальноекономічна оцінка впливу пандемії на бізнес та домогосподарства України станом на червень 2020 року $84 \%$ домогосподарств втратили дохід, а $43 \%$ мають принаймні одного члена родини, який втратив роботу.

Відновлення після цього шоку не буде легким завданням, але 3 появою на горизонті кількох вакцин з'явилася надія. Однак ця надія може швидко розвіятися, якщо ми повернемося до старих моделей поведінки та способів мислення, ігноруючи потенційно успішні шляхи, які стоять перед нами на шляху до зеленої економіки.

Зелена економіка $є$ соціально інклюзивною, виробляє дуже мало вуглецю та ефективно використовує ресурси. Зростання зайнятості та доходів в умовах зеленої економіки спричиняється державними та приватними інвестиціями в ті види економічної діяльності, які дозволяють зменшити викиди вуглецю та забруднення, підвищити стійке виробництво енергії та ефективність використання ресурсів - і все це одночасно з запобіганням втраті планетарного біорізноманіття. У поєднанні між собою ці компоненти можуть спричинити те, що називають «великим перезавантаженням» світової економіки після року локдаунів та соціально-економічних наслідків боротьби 3 пандемією COVID-19.

Наразі в цій сфері спостерігається значна кількість нововведень, які стають підгрунтям для проривних рішень щодо швидкого поліпшення економічних і соціальних умов. Значна частина цих нововведень, які з'являються нині на ринку, застосовується $з$ метою трансформації реальної економіки та фінансів i, як наслідок, виведення світу на «зелений шлях».

Політики також дедалі частіше намагаються потрапити на борт «зеленого» судна: останні два п'ятирічні плани в Китаї були спрямовані на формування зеленої економіки та стимулювання розвитку зелених фінансів. Останнє містить у собі активізацію інвестиційних потоків, які призначені 
для проєктів у галузі сталого розвитку та виробництва екологічно чистих продуктів, і підтримують формування необхідних умов. Визначення «зелені фінанси» це фінансові потоки (банківські, мікрокредитні, страхові та інвестиційні) 3 державного, приватного та некомерційного секторів 3 урахуванням пріоритетів сталого розвитку.

У грудні 2019 року Європейський Союз прийняв Європейський зелений курс (ЄЗК), який передбачає досягнення «кліматичної нейтральності» на європейському континенті до 2050 року. Для досягнення цієї мети СС планує залучити як приватні кошти, так і державні «зелені» фінансові ресурси. У жовтні 2020 року Україна заявила про свою готовність активно співпрацювати з СС та імплементувати положення ЄЗК. Уряд також заявив, що буде активно підтримувати СС у його намірі досягти кліматичної нейтральності всього континенту до 2050 року.

Побудова зеленої економіки в Україні зараз $є$ стрижнем Угоди про асоціацію між Україною та Європейським Союзом, яка включає перелік відповідних директив і нормативних актів, що полегшують перехід до зеленої економіки. Реалізація цих правових актів носить добровільний характер, але може розглядатися як передумова для повної економічної інтеграції України з СС.

Зважаючи на це, Україні слід більше інвестувати в освіту, щоб сформувати кваліфіковану робочу силу й експертів у сфері зеленої трансформації бізнесу та зелених фінансів. Країні конче необхідні такі таланти.

Є політичні, економічні та технічні причини, чому процес зеленої трансформації в Україні йде такими повільними темпами. У політичному плані зелений вимір поки що не інтегрований або не повністю інтегрований в порядок денний українського парламенту та національного уряду, проте це можна змінити.

Економічні причини пов'язані з фінансовою системою, яка занадто сильно покладається на вуглецемісні галузі та викопне паливо.

Технічні причини: згідно 3 Енергетичною стратегією України, частка відновлюваної енергії в загальному міксі первинного постачання повинна зрости до 25\% до 2035 року. Для досягнення цієї мети потрібно буде повністю відновити всю інфраструктуру розподілу енергії за допомогою більш сучасних технологій, наприклад, шляхом встановлення «розумних мереж» [2].

Україна в цілому підтримала Європейський зелений курс, тому такі процеси рано чи пізно повинні відбутися і в нас. Що потрібно зробити зараз, так це оцінити фінансові потреби та розробити стратегії залучення приватного фінансування. Логіка проста: якщо наша система буде продовжувати працювати за старими принципами, ми не зможемо приєднатися до енергетичної системи ЄС та його ринку, стара система продовжуватиме витрачати енергію та ресурси, і ми не виконаємо своїх зобов'язань в рамках Паризької кліматичної угоди.

Зрештою, саме з цих причин українському бізнесу доведеться піти «зеленим шляхом», якщо він хоче досягти успіху. Вже зараз стало дуже складно отримувати прямі кошти на фінансовому ринку без оцінки екологічних, соціальних та управлінських ризиків для бізнесу. Без такої інформації та відповідних рейтингів від визнаних агентств жодна біржа або фінансова установа не зможе надати кредитів для «зеленого переходу».

Агропромисловий сектор $\epsilon$ найбільш перспективним із точки зору «озеленення» України. Це один з небагатьох секторів в Україні, який орієнтований на ринок. Його діяльність уже реформована 3 урахуванням вимог ринку $Є C$, куди експортується значна частина української продукції. Українським компаніям без змін неможливо рухатися вперед, i, отже, потрібно внести «зелені зміни» у свої компанії.

Наш успіх в агропромисловому секторі може бути використаний як натхнення й орієнтир для інших підприємств. Взявши зелений курс, Україна не лише зміцнить свої позиції на ринку $Є С$, а й підвищить свої шанси отримати прямий доступ до приватних «зелених» фінансових ресурсів. Зелена економіка і зелені фінанси для України - це не питання вибору, а питання економічного виживання в прийдешньому столітті.

Реалізація нових заходів Європейського зеленого курсу буде вимогливою і трудомісткою, але за підтримки Уряду України український бізнес ліпше підготується до подолання викликів і досягне успіху на європейських ринках. Коли український бізнес досягне успіху, то вся країна виграє від підвищення рівня зайнятості та збільшення податкових надходжень на громадські товари та послуги.

Це - виснаження земельних ресурсів через недотримання сівозміни, забруднення водних об'єктів та значні викиди в атмосферу внаслідок використання підприємствами застарілого обладнання. Так, за даними Продовольчої та сільськогосподарської організації ООН 6,5 мільйона гектарів грунтів в Україні є деградованими та не придатними для ведення сільського господарства 
Діяльність сільськогосподарського сектору повинна бути спрямована на використання сталих практик, таких як органічне виробництво, точне землеробство, дотримання стандартів добробуту тварин тощо.

Ситуація в Агропромисловому комплексі України є одним з основних секторів економіки та складає близько 10\% ВВП України за 20192020 маркетинговий рік. За цей же період експорт продукції АПК склав майже 40\% від загального експорту.

Сільськогосподарські угіддя займають близько 41,4 млн га, з яких 79\% - орні землі. При цьому Україна має один з найбільших показників у світі по розораності земель - 54\% території країни 84 , але дуже низьку ефективність використання земель та продуктивність АПК. Щорічно збільшується відсоток еродованих земель, зокрема внаслідок оранки. У попередній Стратегії державної екологічної політики України на період до 2020 року було задекларовано зменшення площ орних земель шляхом виведення із користування чи консервації деградованих, малопродуктивних та техногенно забруднених сільськогосподарських угідь тощо [3].

Серед прийнятих нормативно-правових актів Закон України «Про основні принципи та вимоги до органічного виробництва, обігу та маркування органічної продукції» від 10 липня 2018 року № 2496-VIII [4].

Закон України «Про державний контроль за дотриманням законодавства про харчові продукти, корми, побічні продукти тваринного походження, здоров'я та благополуччя тварин» від 18 травня 2017 року № 2042-VIII [5] та Закон України «Про безпечність та гігієну кормів» від 18 травня 2017 року №2042-VIII [6]. Закон про органічне виробництво не впроваджений, адже триває процес прийняття підзаконних актів, який повинен врегулювати правила та процедури ведення органічного сільського господарства. Хоча органічне виробництво розвивається в Україні з початку 2000-х років, його частка в загальній площі земель сільськогосподарського призначення станом на 31.12.2018 року становить всього 0,7\%. Прийнято ще один важливий закон «Про інформацію для споживачів щодо харчових продуктів» від 6 грудня 2018 року № 2639-VIII. Закон визначає вимоги до виробників щодо надання повної та достовірної інформації про харчові продукти, зокрема зазначення інформації про вміст алергенів, харчових добавок та інших показників. Впровадження закону вже почалось. Важливим для сталого розвитку сільського господарства $€$ й ухвалення Закону України «Про оцінку впливу на довкілля» від 23 травня 2017 року № 2059-VIII для запобігання можливим наслідкам від агропромислової діяльності на довкілля [7].

Проте неврегульованими залишаються питання адаптації до зміни клімату, хоча наприкінці 2019 року була розроблена Стратегія запобігання та адаптації до зміни клімату сільського, лісового, мисливського і рибного господарств України на період до 2030 року.

Висновки. Для вирішення визначених завдань та досягнення цілей сталого розвитку потрібно зосередитись на таких завданнях: Забезпечення сталого первинного виробництва; Стимулювання сталих практик у харчовій промисловості, роздрібній торгівлі та сфері надання послуг проживання та харчування; Сприяння сталому споживанню та переходу до здорового харчування; Скорочення відходів продуктів харчування.

Для досягнення поставлених цілей пропонуються такі шляхи та кроки:

1. Підтримка органічного виробництва: виконання програм 3 підтримки виробників органічної продукції; здійснення заходів, спрямованих на підвищення рівня обізнаності виробників стосовно переваг ведення органічного виробництва.

2. Збільшення виробництва органічної продукції: розроблення програм фінансової та дорадчої підтримки виробників органічної продукції; залучення більшої кількості виробників до ведення органічного виробництва шляхом удосконалення державного регулювання в зазначеній сфері

3. Забезпечення розвитку сталого виробництва: заохочення сталого сільськогосподарського виробництва, захисту навколишнього природного середовища і тварин, поширення застосування методів органічного виробництва і використання біотехнологій, «кліматично розумного» сільського та лісового господарства із скороченням викидів парникових газів та адаптацією до зміни клімату, сталого управління природними ресурсами та збереження i примноження біорізноманіття. 


\section{Список літератури:}

1. Постанова Кабінету Міністрів України «Про затвердження Національної економічної стратегії на період до 2030 року» від 03.03.2021 p. № 179. URL: https://www.kmu.gov.ua/npas/pro-zatverdzhennyanacionalnoyi-eko-a179.

2. Розпорядження Кабінету Міністрів України «Про схвалення Енергетичної стратегії України на період до 2035 року “Безпека, енергоефективність, конкурентоспроможність” від 18 серпня 2017 р. № 605-p. URL: https://zakon.rada.gov.ua/laws/show/605-2017-\%D1\%80\#Text

3. Закон України «Про Основні засади (стратегія) державної екологічної політики України на період до 2030 року» від 28 лютого 2019 року № 2697-VIII. URL: https://zakon.rada.gov.ua/laws/show/2697-19\#n14

4. Закон України «Про основні принципи та вимоги до органічного виробництва, обігу та маркування органічної продукції» від 10.07. 2018 року № 2496-VIII. URL: https://zakon.rada.gov.ua/laws/ show/2496-19\#Text

5. Закон України «Про державний контроль за дотриманням законодавства про харчові продукти, корми, побічні продукти тваринного походження, здоров'я та благополуччя тварин» від 18.05.2017 року № 2042-VIII. URL: https://zakon.rada.gov.ua/laws/show/2042-19\#Text

6. Закон України «Про безпечність та гігієну кормів» від 18.05. 2017 року № 2042-VIII. URL: https://zakon.rada.gov.ua/laws/show/2264-19\#Text

7. Офіційний веб-сайт Міністерства аграрної політики та продовольства України. URL: www.minagro.gov.ua

\section{Hurskyi M.M. MECHANISM OF GREEN COURSE REGULATION IN THE AGRICULTURAL SECTOR OF UKRAINE}

In the article on the example of the application of organic production and the green exchange rate in the agricultural sector of the economy of Ukraine, the issue of the mechanism of regulation of the green exchange rate in the agricultural sector of the economy is revealed; recommendations are offered to public authorities and local governments to increase the efficiency of the use of budget funds allocated for the development of the agricultural sector and agriculture of the state. Building a green economy in Ukraine is now at the heart of the Association Agreement between Ukraine and the European Union, which includes a list of relevant directives and regulations that facilitate the transition to a green economy. The implementation of these legal acts is voluntary, but can be seen as a prerequisite for full economic integration of Ukraine with the EU. The political, economic and technical reasons why the process of green transformation in Ukraine is proceeding at such a slow pace have been identified. Politically, the green dimension is not yet integrated or fully integrated into the agenda of the Ukrainian parliament and national government, but this can be changed. The economic reasons are related to the financial system, which relies too heavily on coal-intensive industries and fossil fuels. To achieve these goals, the following ways are proposed: 1) support for organic production: implementation of programs to support producers of organic products; implementation of measures aimed at raising awareness of producers about the benefits of organic production; 2) increasing the production of organic products: development of programs of financial and advisory support for producers of organic products; attracting more producers to organic production by improving government regulation in this area; 3) ensuring the development of sustainable production: promoting sustainable agricultural production, protecting the environment and animals, disseminating the use of organic production methods and the use of biotechnology, "climate-friendly" agriculture and forestry with reduced greenhouse gas emissions and adaptation to climate change, sustainable natural management resources and conservation and enhancement of biodiversity.

Key words: public administration, state regulation, agro-industrial complex, state support of agro-industrial complex, agricultural enterprises, personal peasant farms, green course. 